\title{
The Characteristics of Culture and Religions in Ho Chi Minh City, Vietnam: Processes of Acculturation, Transformation and Accumulation
}

\author{
Truong Van Chung*
}

\begin{abstract}
Ho Chi Minh City is a city which has received and accumulated many cultures and religions from around the world, from Oriental culture to Western civilization, from West Asian and East Asian cultures to South Asian and Southeast Asian cultures. The cultures of some African and Latin American countries have also arrived recently. Most world religions, regional religions, national religions and even new religions are present in the city. The characteristic of religions and cultural identities of Ho Chi Minh City is in the process of transformation, receipt and selection of the cultural and religion elements of those cultures. Based on the research results of a scientific research on the topic, "Cultural and religion life in Ho Chi Minh City in the era of international integration", we would like to share some opinions about the characteristics of culture and religions in the process of cultural exchange, acculturation and accumulation of $\mathrm{Ho}$ Chi Minh City from traditional to modern stage.
\end{abstract}

Keywords: Characteristics of culture; Characteristics of religion; Processes of acculturation; Transformation and accumulation; Cultural identities; International integration

* Centre for Religion Studies, the University of Social Sciences and Humanities, Vietnam National University, Ho Chi Minh City; crsh@hcmussh.edu.vn 
In a flat and changing world, the issue of culture and national culture has always become the top concern of the social sciences and humanities in all countries. Vietnam today is on the way to international integration and particularly interested in the "international integration and absorbing the essence of the world culture while still keeping the ethnic cultural identities." Although Ho Chi Minh City is a young and modern city of just above 300 years of history and development, it has been a fast-growing city, always at the forefront in the field of economic development and a major center of culture, education, science and technology in Vietnam. In terms of culture and religion, Ho Chi Minh City is also a centre point of cultural and religious flows of many ethnic groups and a fertile land for the introduction and emergence of new cultural forms and forms of religion. This paper is based on the research topic, "The culture and religions in Ho Chi Minh in the context of international integration", to share more about the charateristics of culture and religions in Ho Chi Minh City as a result of a process of acculturation, transformation and accumulation.

\section{The cultural characteristics of Ho Chi Minh City from the standpoint of comparison and acculturation.}

We need to start from the basis of social existence, demographic and population structure in order to research on the culture and religion characteristics of $\mathrm{Ho} \mathrm{Chi}$ Minh City. According to the results of population census in Ho Chi Minh City in recent years, we found a sudden increase in population in the past 20 years. For instance, according to the population census in October 1979, the population of Ho Chi Minh City was 3,419,977 people. Ten years later in April 1989, the population was 3,988,124, increasing 568,147 people. In April 1999, the population was 5,037,155 people, increasing one million people compared with the year 1989 and in April 2009, the population was 7,162,864 people, increasing two million people compared with the year 1999. The population of Ho Chi Minh City was 7,251,138 people in May 2011.1

\footnotetext{
${ }^{1}$ Website: pso.hocm.gov.vn/ niêm giám thống kê 12/2011 Tp.HCM
} 
Thus, Ho Chi Minh City is the most populous city in Vietnam, with a growth rate of $3.56 \%$ per year, accounting for $22.32 \%$ of population growth of the country. This number has excluded an average of two million visitors every year. It is observed that the natural growth rate is only about $1.07 \%$ while the mechanical growth rate is up to $2.5 \% 2$ and the population tends to increase rapidly in the newly established districts. The rapid mechanical population growth in Ho Chi Minh City will lead to many problems in social life such as living standard discrepancy between the rich and the poor, social security, culture and religion issues.

When analyzing the ethnic composition, we found that the Vietnamese (Kinh ethnic group) is of $6,698,124$ people or $93.52 \%$, making up the majority of the population of Ho Chi Minh City, the Chinese come second with a community of 414,045 people, representing $5.78 \%$ of the city population, and the rest are 24,268 people of the Khmer group and 7,819 Cham people. According to statistics, there are 54 recognized ethnic groups of Vietnam residing in Ho Chi Minh City, one of whom, the La Hu group, has only one person. There are also more than 1,000 residents from other countries who have resided here for a very long time such as Indian, Pakistani, Indonesian, and French. This is not to mention about 5,000 people from other countries recently living and working in Ho Chi Minh City such as Korean, Taiwanese, Australian, Japanese, Russian, Spaniard, Italian etc...It can be said that in terms of ethnography, Ho Chi Minh City is at the highest level of multi-ethnicity which is the basis of a multi-cultural and multi-religious society and has significant impacts on its religion and cultural characteristics. It is worth noting here that from the geo-cultural perspective, different ethnic groups in Ho Chi Minh City densely populate in certain districts. For instance, the Chinese community mainly reside and do business in District 5, 6, 8, 10 and 11, and especially in Cho Lon area (District 5 and 6), making the famous "China Town" in Saigon ( old name of Ho Chi Minh City). Most migrants live in the districts far from downtown such as District 9, 12, Tan Phu District, and Binh Chanh District etc...,

\footnotetext{
${ }^{2}$ Website: pso.hocm.gov.vn/ niêm giám thống kê / dân số lao động 12/2011 Tp.HCM
} 
creating new neighborhoods with new names such as Thu Duc, the export and processing zones, Linh Trung-Thu Duc area. Foreigners make the "Korea Town" on Pham Van Hai Street, Tan Binh District, "Japan Town" on Ho Van Hue Street, Phu Nhuan District, "Backpackers Street" on Pham Ngu Lao Street, District 1. Foreigners who are working and living with their families mainly stay in Phu My Hung area in District 7.

The Vietnamese group live in all districts but due to religious and cultural factors densely populated in different areas. For instance, Vietnamese Catholics mainly reside in three areas:

1. The northern area of Saigon (mainly located in the North side of Go Vap District): majority of Northern Vietnamese live in Nga Ba Ong Ta area, Xom Chieu - Khanh Hoi area (District 4), Xom Moi (Go Vap District) etc...

2. The western area of Saigon: areas along Cach Mang Thang Tam Street from Le Thi Rieng Park to Truong Chinh-Cong Hoa intersection and some surrounding roads such as $\mathrm{Au}$ Co Street, Doc Lap Street, Tan Huong Street, Tan Son Nhi Street.

3. The southern area of Saigon: areas along Pham The Hien Street, including a portion of Ward 4, 6, 7, and 8. The earlier Central Vietnamese migrants have populated in areas along Nga Tu Bay Hien area and Hoang Hoa Tham Street, making these areas become known for certain businesses such as weaving, wood carving, stone carving, and mason ward. In recent years, they often reside in suburban districts. The ethnic diversity of Ho Chi Minh City has created unique characteristics of the city and made people regard it as a "multifaceted Saigon", "Saigon Soup", "Saigon Tap Pi Lu" etc...

Researching the cultural layers and institutions of Ho Chi Minh City reveals a diverse and multi-layered culture, reflecting a cultural history of the city from a traditional to a modern stage. The innermost layer is the convergence of local cultures from three regions, the North, the Central and the South. Professor Vu Khieu had said, " like Thang Long (the old name of Ha Noi), Saigon has soon performed two basic functions of an economic, social and 
cultural centre. These two are to integrate and to shine. The essences from every part of the country gradually integrated and gathered here, which then are advanced and become a shining central point of civilization." 3 Since the time of reclaiming marshlands until now, the cultures of the North, the Central and the South have deeply rooted in the Southern culture. Right from the time when Lord Nguyen Phuc Chu ordered Nguyen Huu Canh to pacify Sai Gon, the process of integration of cultures of the sea, the plain and the highland has started. Earlier, Southern culture had also acculturated with the cultures of Cham people and South Khmer people. The Northern Vietnamese with their Northern Delta culture migrated to the South either in ancient time or in mass migratory movements in 1954 and 1975, leaving marks on the Southern culture with the philosophy of well planning ahead, strictness, order, discipline, harmony and moderation. The culture of social organization led to the model of villages or wards which do the same business with the spirit of "cung hoi, cung phuong" (same job, same group) to protect each other. This culture along with the life style and cuisine of the North has created the cultural characteristics of the Northern plain in the South. The sea culture of the Central migrants with the spirit of "len non, xuong bien" (up to the mountain, down to the sea), "an song, noi gio" (eat with the waves, talk with the winds), working hard, being hardy, resourceful, adventurous, dynamic, and rapidly adapting to any situation has integrated with and contributed its own essence to the culture of Saigon.

The settlement of the Cham people in Ho Chi Minh City was a long and indirect process, which started at the same time as when the Central Vietnamese moved southward. The Cham did not migrate to Ho Chi Minh City directly but through Cambodia to An Giang Province and then up to Saigon ${ }^{4}$. The presence of the Cham

3 Saigon - Ho Chi Minh City: people and culture in the course of development, Tre Publishing House, 2002, p.18

4 There is theory that the movements of many Cham groups of Champa Kingdom started very early in history. In 1471, they settled in islands of Malaysia and Indonesia. After that, some moved to Thailand, Cambodia and then An Giang province in 
community led to the development of a major Islam community in Ho Chi Minh City. The Cham people live in all districts of Ho Chi Minh City5, but mostly in District 8 with two mosques located at Rach Ong area and Duong Ba Trac Street. Being influenced by Islam and urban life, the social organization of the Cham community in the city has changed to patriarchy with many changes in their material and spiritual life. However, they still keep some distinctive religious and cultural traditions. For instance, the matriarchal traits can be seen in family relations and weddings. Weddings are still organized at the bride's house and there are 50 percent of couples living with the bride's family after marriage ${ }^{6}$. The Southern Cham people are a small community numbered around 2,000 and mainly reside in District 8. Their cuture and spiritual life are greatly influenced by Islam as most of them are Muslims.

The Khmer people settled in the South at an early stage and have a distinctive culture. The culture of the Southern Khmer people is part of Southern culture. In the process of cohabitant and acculturation with other ethnic groups, the Khmer people in general and in Ho Chi Minh City particularly have enriched the culture of Ho Chi Minh City. However, the lifestyle and thinking of the Khmer community in Ho Chi Minh City has changed significantly. Phum and Soc (hamlet) are no longer the basic social units and temples are not the only centres for religious, social and cultural activities of the Khmer people in Ho Chi Minh City. Though the religion of the Khmer people is still Theravada, they

Vietnam. Please refer to the science project of "Islam community in Ho Chi Minh City and the relation with Souh East Asia region" by Ho Chi Minh Centre of Social Sciences and Humanities, 2000, p.48

${ }^{5}$ According to Vietnam Cham Islam Association, the number of the Cham community in 1976 was 4607; in 1988 was 4470; in 1991 was 4504. According to Ho Chi Minh City Statistic Bureau, there were 2991 Cham residents in 2005.

${ }^{6}$ Ngo Van Le, "Cham cuture from religious aspect", Conference on Cham culture, General University, Ho Chi Minh City , 1995. 
live closely in small groups in all districts of Ho Chi Minh City 7 and are also influenced by the culture and religions of the Chinese and Vietnamese. Therefore, there are changes in the material and spiritual culture of the Khmer people in Ho Chi Minh City such as in housing, dressing, cuisine, and traditional rituals.

It is said that the Southern culture in Ho Chi Minh City had a strict local institution with its own identity creating a solid spiritual foundation of society. The additional processes after that were only to enrich and diversify the culture. From geo-cultural aspects, Saigon-Ho Chi Minh City is the gateway of East-West cultural exchange, creating favorable conditions for the integration of accumulation with the essence of the world cultures and cultural values of the era. Historically, Saigonese have witnessed three cultural waves in different eras.

The rebellious troops who were against the Ming Dynasty and supported the Qing Dynasty in China seeked refuge in the South West in the sixteen century, bringing with them the Chinese culture of early modern era. The Chinese population is of 474,712 people, accounting for $14.41 \%$ of the city population ${ }^{8}$. Due to the complexity in names and languages of different Chinese ethnic groups, we would like to share the definition of Chinese by Nghi Doan, the author of the writing, "The revolution traditions of the Chinese communities in Ho Chi Minh City" as below:

"The Chinese in Ho Chi Minh City were suppressed people who came to the new land in the early days and contributed to the establishment and construction of the city. In this process, they have established a close, sincere and loving relationship with the Vietnamese community for generations. Having settled in the land for generations with the solidarity, harmonious and united spirit

${ }^{7}$ According to the Statistic of Ho Chi Minh City Religion Board, in October 1998, the Khmer people resided in all districts in the city but mostly in Tan Binh Dicstrict (589 residennts), District 6 ( 356 residents) and Binh Thanh District (318 residents).

8 According to Census Board of Ho Chi Minh City, 1994 Census, $\mathrm{p}$ 37. 
has made the Chinese community become the real and natural owners of the area." 9

According to Mac Duong, a sociologist, the social status of the Chinese as citizens of Vietnam and residents Ho Chi Minh City has been affirmed for hundreds years, especially since 1975 10. The Chinese in Ho Chi Minh City are of different groups with different native languages such as Guang Dong community (56.5\% of total number of Chinese in Ho Chi Minh City), Zhao Chou community (34\%), Fu Jian community (6\%), Hai Nan community (2\%), and He community (2\%). The Chinese have relatives and countrymen in all over the world, especially in South East Asia. On one hand, the Chinese in Ho Chi Minh City have their own cultural identity, deeply influenced by Chinese culture and traditions which can be seen in business practices, lifestyle, behaviors and traditional festivals such as the Lantern Festival, Shangsi Festival, Qingming Festival , Dragon Boat Festival etc... On the other hand, having been cohabited with the Vietnamese, their culture has transformed, containing some Vietnamese cultural traits and " is an important part of the culture of Ho Chi Minh City." 11 The Chinese community has grown strongly and established their own cultural identities in Ho Chi Minh City. They densely populate in an area known as China Town in Saigon. Chinese culture has contributed to the diversification of religion, cuisine, clothing, and languages in Ho Chi Minh City.

When the French occupied Saigon in 1861, Western European culture penetrated into the society of this city in the guise of protection. Putting aside the negative elements of colonialism, the positive elements of Western culture had been transmitted by the

${ }^{9}$ Nghi Doan, Revolutionary tradition of the Chinese in Ho Chi Minh City, Ho Chi Minh City Publishing, 1987, p 146.

10 Mac Duong, the Chinese society in Ho Chi Minh City after 1975: potential and development, Social Science and Humanities Publishing, 1994, p 24.

11 Mac Duong, The Chinese society in Ho Chi Minh City after 1975: potential and development, Social Science and Humanities Publishing, 1994, p 98. 
French such as engineers, doctors, priests, scientists etc...Western spirit was cultivated in this land, blowing a new cultural wind with new areas of knowledge such as philosophy, religion, aesthetics, archeology, literature etc... Rev.Thien Cam precisely commented that, "Without integration of Christian spirit into Vietnam culture, Vietnam culture is still beautiful with all of its uniqueness, but the integration of Christianity into our country's culture has enriched and diversified it in the same way Confucianism, Taoism and Buddhism have done before. In this process of integration, there is no lost. On the contrary, the Vietnam culture and religions, especially Christianity, have been added other unique features."12

The American culture arrived in Saigon in the 1960s of the twentieth century along with the presence of American troops. A wave of modern Western culture with both positive and negative features arrived which were pragmatism, individualism, neopositivism, existentialism, materialistic and practical lifestyle, and hippy movement etc..., creating a chaotic cultural environment and risks of indigenous culture being overturned, broken and uprooted. However, Saigon culture has demonstrated their strong capabilities in receiving positive elements of modern Western culture such as natural sciences, technologies, commerce while maintaining their own cultural identities without being lost or culturally dominated.

After the unification, in the light of Marxism-Leninism and Ho Chi Minh thoughts, Ho Chi Minh culture has integrated into the culture of the whole nation under socialist system and as well with the culture of other countries all over the world. Beside the ideological struggle against harmful old cultural relics, the culture of Ho Chi Minh City has aimed at a new advanced culture and producing people who are full of national identities, demonstrating concepts of new culture and new people and some practical cultural movements such as good people, good action, young volunteers, living and working under the law (the law abiding spirit). New cultural institutions were introduced such as The House of Culture, The House of Traditions, clubs, revolution museums, libraries, parks, and entertainment parks. In the third millennium, Ho Chi

12 Thien Cam, " Is there a Catholic culture in Vietnam?", Documents for internal use, Hue, 2000, p. 31 
Minh City has been firmed in the construction and development of an advanced culture imbued with national identity to become a major gateway for collaboration and dialogue in the context of globalization. It is predicted that, culturally, Ho Chi Minh City will continue to receive many new cultural flows which may be very new and strange from around the world and contains both opportunities and challenges. The cultural history of Ho Chi Minh City has also demonstrated that its culture has selectively acquired the world values and cultural essence and successfully decoded the cultural and lifestyle challenges. Considering the movement, acculturation, fusion and accumulation from traditional to modern culture of Ho Chi Minh City, we have identified the following cultural characteristics:

\section{A global culture}

The history and culture of Ho Chi Minh City is a process of acquiring and integrating cultural flows from all over the world. The culture of Ho Chi Minh City contains many elements of the world culture, especially the trend of globalization. Currently, with the international economic integration, many modern and new flows of culture have been accepted into the social and cultural life, creating the multi-faceted culture of the city. In addition to literature, art, contemporary music, lifestyle, and culinary, some new cultural trends have emerged as a new phenomenon which help to further clarify the nature of global culture of Ho Chi Minh City.

\section{The openness, tolerance, dynamic and non-prejudice of culture}

Regarded as "the good land where birds will come", Ho Chi Minh City does not have any prejudice of religion and culture either in the past or at present. All cultural flows and elements are accepted, accumulated, selected, and transformed into the city culture. This process is also a result of the chivalrous spirit, generous lifestyle, and a sense of tolerance in the general character of the Saigonese and the Southerners.

Tran Bach Dang remarked, "Most writers and artists related to Saigon are from other places and the ones originally from Sagon are of a small number. That reality is still going on today which is 
not a surprise as we know Saigon has a political, economic, and cultural status, like other major cities in the world. The best shoemakers and tailors are called "Saigon shoemaker and tailor" whose hometowns are in the Red River delta. "Pho Saigon" (a tranditional noodle) is now very popular, cooked by the Northerners." 13

The religions are interpreted as a cultural phenomenon in the sense, "All religions are good. All are for the pursuit of good things for people. All religions in Ho Chi Minh City are not discriminated but live together in harmony. However, the cultural and religion trial can not change the national cultural identities but to add new values to the culture and to themselves ${ }^{14}$. New religions in Ho Chi Minh City have inherited the same spirit. They have not been accepted, but yet rejected by society, as in the case of new religions in North America and Europe in 1960s and 1970s of the twentieth century.

\section{Strong capacities and inner force of culture}

The capacities and inner force of a culture are firstly the values and spiritual identities of a community. They are at the innermost layer and capable of accutulrating and integrating different cultural phenomena and trends selectively from outside, measuring against a stable standard scale of values and identities. The culture of Ho Chi Minh City is a strong and firm system of spiritual values and identities such as patriotism, unity, solidarity, love like, chivalrous spirit, generosity, dare to think, dare to do, tolerance, altruism, easily adapt to circumstances etc ... which have formed the capacities and inner force of the culture. This is also the common spiritual values and identities of Vietnam but they are demonstrated in a stronger, more determined and clearer way in Ho Chi Minh City. Due to strong capacities and inner force, the culture of Ho Chi Minh City has confidently received all flows of culture and religion coming without fear of being faded or

${ }^{13}$ Tran Van Giau (Ed.), Cultural geography of Ho Chi Minh City, Book 1, Ho Chi Minh City Publishing House, 1987, p. 623

14 Phan Xuan Bien, The South East: people and culture, National University Publishing House, Ho Chi Minh, 2004 
dominated. It is also active and creative in dealing with all challenges and conflicts of culture and religion and dare to change and refresh in the cultural exchange and acculturation.

The capacities and inner force of the culture of Ho Chi Minh City has been challenged and trained in the struggles to protect the values of national culture regard to ideology and culture. The capacities and inner force has the ability to shine and to spread all over. Therefore, new cultural movements can be introduced or appear in Ho Chi Minh City easily but they will be subject to the acculturation to the local culture.

\section{Characteristics of religions in Ho Chi Minh City}

Ho Chi Minh City is a city where we can see both the diversity of religious forms, the representativeness and distinctiveness of Southern religions and its own characteristics of religions influenced by the land, the people, the culture and the traditions etc... This is due to a long process of different ethnic communities living together in the same land and being affected by the same social and political changes. Therefore, it is necessary to study the religions in Ho Chi Minh City to find out their characteristic theoretically and practically, contributing to the study of new religions in Ho Chi Minh City. The culture and religions of ethnic communities in Ho Chi Minh City are parts of the Southern culture and religions. They share common characteristics with Vietnamese culture but still have the characteristics of the South and their own distinctiveness. Because of this, researching the culture and religions in Ho Chi Minh City should be conducted in the historical, cultural and religion settings of the South, especially with the religion and cultural interaction between the ethnic communities in Ho Chi Minh City in history. This part presents the characteristics of religions in Ho Chi Minh City from a cultural perspective.

The distinctive and traditional characteristic of religions in Ho Chi Minh City is the diverse forms and complex nature of religions. This is obviously reflected in the reality of religion in Ho Chi Minh City. According to statistics released by Ho Chi Minh City Religion 
Board, Ho Chi Minh City has almost all religions of Vietnam ${ }^{15}$ Beside Buddhism, Catholicism, Protestantism, there are local religions such as Caodaism, Hoa Hao Sect, Tinh Do $\mathrm{Cu}$ Sy (Buddhist Pureland), Tam Tong Mieu (the Temple of Three Religions), and Dao Minh Su (Good Master Sect). Other religions such as Hinduism, Baha'i, and Islam are also diversified though they have a small number of adherents. It is not to mention about different branches of Buddhism, Catholicism and Protestantism in Ho Chi Minh City. With regard to Buddhism, there are Khat Sy sect, Khmer Theravada Buddhism, Vietnamese Theravada Buddhism, and Mahayana Buddhism. With regard to Catholicism, there are Congregation of the Holy Cross Lovers, the Congregation of the Most Holy Redeemer, Congregation of the Mother Coredemptrix, the Society of Jesus, Our Lady of des Mission, the Congregation of the Blessed Sacrament, Order of Friars Minor (Franciscans), Dominicans, the Congregation of Poor Brothers. With regard to Protestantism, there are Evangelical Church of Viet Nam, Seventh Day Adventist Church, Grace Baptist Church, Jehova witness, Catholic Mission Association etc... Although the Islamic community Korean Protestantism in Ho Chi Minh has a modest number of adherents $(0.13 \%$ of Ho Chi Minh City population), it has four sects which are Islam of Melayu community (Malaysia, Indonesia), Islam of Indian and Pakistani communities, Islam of Jawaku community ${ }^{16}$, Islam of Cham community. There are also new forms of religions which are described by foreign scholars as "new religious movement".

15 According to the statistic of Ho Chi Minh City Religion board in 2002, the adherents number are as below:

Buddhism: 1.672.000, Catholicism: 645.840, Cao Dai: 42.067, Hoa Hao Buddhism: 1.550, Islam: 5.480, Protestanism: 65.397, Tinh Do Cu Si Phat Hoi: 36.575, Dao Minh Su: 1000, Baha'i:300

16 Jawakus are Chams who were "Malaysialized" and move to Cambodia where they continued to be "Khmerzied". Jawakus speak a language which is a mixture of Malay and Khmer language. They have settled at Rach Ong ara and have their owns mosque in Pham The Hien Street, Ward 2, District 8, Ho Chi Minh City. 
In our opinion, there are various reasons for this diversity but the main reason is the multi-ethnicism and multiculturalism of the population and the convergence of multiple cultural flows along with changes of the era which created diverse religious forms and characteristics. The Vietnamese started to settle in the South in the seventeenth century due to economic and political reasons, bringing along with them three religions of Confucianism, Taoism and Buddhism of which Buddhism is the main religion ${ }^{17}$. They have been getting along with the Chinese, Khmer and Cham communities for three centuries in the same geographical and ecological area and creating a diverse but unified culture which is the ground for acculturation and religious psychological transformation. This can be demonstrated in the fact that there are different sects of Buddhism in the South Vietnam such as Theraveda Buddhism, He Phai Khat Sy, Pureland Buddhist Sect, Tu An Hieu Nghia Sect, Hoa Hao Sect and other Buddhist associations like South Vietnam Buddhist Studies Association, Thien Thai Giao Quan Sect, Co Son Mon Hoi Sect, Vietnam Theravada Buddhist Association etc...

The traditional religion of the Khmer people is Theravada Buddhism, the spiritual ground of their traditional social structure in which blood relations and the remains of matriarchy are important elements. Theravada Buddhism still has a great influence on the cultural and spiritual life of the Khmer people but it is not the core element of the life of the whole community. There is religious conversion of part of the community. ${ }^{18}$ Besides taking part in their own ritual activities, the Khmer people also attend festivals of the Vietnamese and Chinese like celebrating the New Year Eve, Chua Ba Festival in Binh Duong, Nghinh Ong Festival in Can Gio, Ky Yen Festival of Binh Dong Temple in District 8, Ky Yen Festival at Truong Tho Temple, Thu Duc etc... The largest temple of

17Ho Chi Minh City Religion Association, Conference on 300 years of Buddhism in Gia Dinh - Sai Gon, Ho Chi Minh City Publishing, 2001, p 88-97.

18 The phenonmenon of conversion to Protestant of the Southern Khmer community. 
Theravada Buddhism is in Tan Binh District where a large number of the Southern Khmer people live.

Beliefs and religions not only play an important part in cultural activities and community spirit of the Chinese but also an organic part which is indispensable to the religion of the city. In terms of cultural anthropology, creeds and religions of the Chinese community are the main environment for creating trends and driving force for personal growth and community consciousness. They are crucial needs in daily life. According to author Phan An, to the Chinese, beliefs are more important than religion. He wrote, “...in regard to religions and beliefs of the Chinese in Ho Chi Minh City, except a few temples like Khanh Van Nam Vien or Chi Truc Lam which are simply Buddhist or Taoist temple, most of the Chinese temples are complexes of beliefs and religions, where beliefs are superior than religions." 19 In fact, religions and beliefs are popular activities of Chinese communities with a whole system of gods and saints, who play a role in ethical education and orientation of behavior and thinking. For instance, worshiping Quan Gong (or Quan $\mathrm{Yu}$ ) educates humanities, courage and trustworthiness and creates a sense of heroism. Worshiping Goddess Thien Hau strengthens the respect towards parents, virtues, and helpfulness. Worshiping Bon Dau Cong appreciates the spirit to overcome hardships, creativity and gather the feeling of being fellow-countrymen and patience. Worshiping God of Wealth satisfies the desire for prosperity and luck in the community etc...These spiritual activities have great influences to religions and beliefs of Vietnamese and Khmer communities. Many Vietnamese and Khmer in Ho Chi Minh City join the Chinese cultural and religious activities such as Tiger Dance, Lion Dance, Dragon Dance and Chinese traditional drama (or "Chines opera"). A large number of the Vietnamese and Khmer people worship the God of the Earth, God of Wealth, and Maitreya Buddha etc...in their houses ${ }^{20}$ like the Chinese.

19 Phan An, Chinese Temples: a distinctive feature of Ho Chi Minh City, Ho Chi Minh City Publishing, 1990, p 9-10.

20 Phan Thi Yen Tuyet, Housing, Dressing and Cuisine of people in Mekong Delta, Social Science Publishing, Ha Noi, 1993, p 273. 
The religion of the Cham people in Ho Chi Minh City also has its own traits. The whole community follows Islam. On one hand, they follow the Islam rituals such as daily praying, doing charity, pilgrimage to Mecca and maintain Islamic traditions and custom. On the other hand, they also have their own distinctiveness like women can attend mosque services and single women do not have to wear veils when going outside etc... The Cham people are allowed to attend cultural and social activities in the city such as singing and sports. Though the religion and culture of the Cham community do not influence other communities significantly, it contributes to the diversity of religions in Ho Chi Minh City.

Major cultural and religious transformation took place in Vietnam in the second half of the Sixteenth century and Ho Chi Minh City was one of the places where these changes happened. In the book Khâm định Việt sủ thông giám cuoong muc, it is written, "in Nguyen Hoa year, under the rule of King Le Trang Tong (1553), there was a businessman called Inikhu who sailed to Ninh Cuong and Quan Anh, belonging to Nam Chau district and Tra Lu village, belonging to Giao Thuy district to illegally converted people to Catholicism." ${ }^{21}$ Based on these records, many researchers on Catholic history consider this year as a milestone for the introduction of Catholicism into Vietnam. After almost 500 years, Catholicism and its values not only affirm its position in the spiritual life of the Vietnamese but also significantly contribute to the material and spiritual culture in Vietnam. Catholicism was introduced to Ho Chi Minh City in 1844 by the establishment of the Tay Dang archdiocese which was under the supervision of Bishop Lefbvre Ngai (18441864) and included Dong Nai, Bien Hoa, Gia Dinh (Saigon), Dinh Tuong (My Tho), Long Ho (Vinh Long), An Giang (Chau Doc) and Ha Tien, Cambodia, and part of South Lao with 23, 000 adherents. Missionaries were the first ones who introduced achievements of

${ }^{21}$ Kham Dinh Viet Su Thong Giam Cuong Muc, Translated version, Hanoi Education Publisher, 2002, p 231 * On 2nd March 1844, Bishop Gregorioban released an Announcement to divide the Southern area into two archdioceses as Eastern and Western archdiocese 
Western civilization into Saigon. They not only spread Catholicism but also Western civilization and among these were bishops in Saigon such as Bishop Jean Mịch 22(1865 - 1873); Bishop Isidore Colombert My 23(1873 - 1894); Bishop Lucien Mosard Mao 24(1899 1920), Bishop Nguyen Ba Tong, the first ordained Vietnamese bishop 25(1932 - 1949) etc. Western civilization and Catholic community has become part of the spiritual, cultural and social life in Ho Chi Minh City. The Vietnamese people started to know astronomy, geography, mathematics, Western medicines, pharmacy, hospitals, and universities (Thanh Nhan University, Minh Duc University etc.). Le Quy Don (1726-1784), a Vietnamese scholar at that time, wrote, "Western priests have mentioned about many new and strange things. Their political theories and calendar are more comprehensive than Confucian theories. They discuss reasonably and logically about geography, the earth, mountains, the seas, rivers, tide and weather. They say there are four continents which are Asia, Europe, Africa and America among which Asia is the largest." 26

22 Bishop Jean Miche Mich (1865-1973) supervised the Western archdiocese including 4 provinces of Bien Hoa, Gia Dinh, Dingh Tuong, Vinh Long with 33000 adherents and 125 parishes.

${ }^{23}$ Bishop Isidore Colombert My (1873-1894) built famous churches and cathedrals in Saigon such as: St. Giuse Church, St. Paulo Church, Cat Minh Church, Notre Dame Catheral in 1877.

${ }^{24}$ Bishop Lucien Mossard Mão ( 1899 - 1920 ) continued to build famous churches such as Cha Tam Church, Chi Hoa Church (1900), Choe Dui Church (1905), Tan Dinh Church.

25 Bishop Gioan Baptista Nguyen Ba Tong (1932 - 1949) achievements were to develop a Catholic community with 82.375 adherents, 27 priests, 80 Vietnamese bishops, 58 parishes, and 152 family groups. (Source: Saigon Diocese: 150 years of Western Archdiocese , Ho Chi Minh City, 1994)

${ }^{26}$ Le Qui Don, Phu Bien Tap Luc, Book I, Social Sciences Publishing House, Hanoi, 1997. 
One of the greatest contributions of Catholicism in Vietnam is the introduction of Latin alphabet to transcript the Vietnamese language, creating a new writing called Quoc ngu (scripts of national language) and bring about a new perception of education and Western advances, broadening the public knowledge, and discouraging the old-fashioned Confucian method of studying and examining. Through Catholicism, The Southerners had opportunities to see master pieces of Western art such as the paintings The last super by Leonard de Vinci, Madonna by Raphael and songs such as Ave Maria, Silent night etc...The Notre Dame Cathedral, Cha Tam Church and St. Jeanne d'Arc Church are master pieces combining both Romanesque and Gothic architecture.

Today, Catholicism's mottos have contributed to a healthy social life in Vietnam. Catholic ethics and morality praise moral values, humanities, honesty, responsibility etc. There are many good samples of Catholics in social activities. For instance, there are nuns who take care of leprosy and HIV/AIDS patients.

The second distinctive characteristic of religions in Ho Chi Minh City is an active and flexible religious life, contributing to the social and cultural development of Ho Chi Minh City and the South in general. This can be seen in many historical events of Ho Chi Minh City such as Thien Dia Hoi (Heaven and Earth Society), Hoi kin (Secret Society), Phan Xich Long Uprising, Buddhism Enlightenment Movement of Luc Hoa Lien Xa Society, Nguyen Van Hien, the first ordained Vietnamese Archbishop of Saigon Diocese appointed by the Vatican Holy See in November 1955, the self-immolation of monk Thich Quang Duc on 11th June 1963, antiwar moment for human rights and democracy of Catholics in 1973. The Government Committee of Religious Affairs has granted Certificate for Religious Practice for 23 religious organizations, among which are 6 new religions as Tu An Hieu Nghia Religion, Tinh Do Cu Si Sect, Baha'i, Dao Minh Su, Tam Tong Mieu, Buu Son Ky Huong and 7 Protestant organizations such as Vietnam Catholic Mission Association, Vietnam Seventh Day Adventist Church , Vietnam Grace Baptist Church , Vietnam Baptist Church, Vietnamese Mennonite Church, Presbyterian Church of Vietnam, and Christian Fellowship Church of Vietnam. Three organizations 
granted organization statuses by the State are Vietnam Catholic Mission Association, Vietnam Baptist Church and Vietnam Buddhist Pure land Association27. All 13 organizations are operating in Ho Chi Minh City. The religious organizations always actively take part in activities and big events of the city and the nation like " building good family, ward and town", " good urban life", " poverty reduction", " flood victims relief" , "Care for poor children", "Free classes for poor children" , "Blood donation" etc... 28 They are always the representatives in uniting and gathering people to join hands in these movements.

Beside frequent religious activities such as Buddhism, Hoa Hao, and Cao Dai adherents worshiping in the first day and fifteen day of the lunar month or going to temples, or Catholicism and Protestantism adherents going to church on Saturday and Sunday, there are also other activities such as weekly club meetings, seminars, conferences, lectures, training courses for adherents from primary to advanced level (B.A level). Especially impressive is vibrant and charitable activities participate in socialization activities in the field of health, education, and contribute greatly to the social security and life stability. ${ }^{29}$

The activities and flexibility of religious life in Ho Chi Minh City reflects the actual urban life on one hand and contribute to the flexibility of the social and cultural life of the city on the other hand. We can learn from this characteristic the deep penetration of religious organization in communities and the increasing degree of religious demand of the people in Ho Chi Minh City. In our opinion, it is necessary for scholars and public administrators to go deeper and do more thorough researches and sociological investigation about this issue.

27 Tran Xuan Hien, "Results of religion policy in 2007", Religous Studies Journal, Vol 3, 2008, p 58-59.

${ }_{28}$ Religion Council, Vietnam National Front, Report on socialized healthcare, education and charity activities of religions in Ho Chi Minh City, 2012.

${ }^{29}$ Religion Council, Vietnam National Front, Report on socialized healthcare, education and charity activities of religions in $\mathrm{Ho}$ Chi Minh City, October 2012. 
The third distinctive characteristic of religions in Ho Chi Minh City is the contemporary feature of religions. In the context of globalization and economic integration of Ho Chi Minh City, religious organizations speed up the modernization process of their organizational systems such as the clergy, the information dissemination and international relations activities.

\section{The Clergy of religious organizations}

All religious organizations have well educated adherents; especially the young clergy are well trained and qualified. Many monks, nuns, priests and pastors study at oversea religious centres. Most nuns and monks in Ho Chi Minh City study at Buddhist universities in India, Japan, China, and Taiwan. The Catholic clergy are trained at Catholic centres and universities in America, Germany and Australia etc... ${ }^{30}$. In addition, the training courses conducted inside Vietnam is also important for upgrading the religious understanding and faith of religious communities. This is one of the motivations for the creativity, flexibility and contemporary nature of religious activities and religions.

\section{Information dissemination}

Religious organizations in Ho Chi Minh City have a diverse and modern information dissemination system, using Internet to promote religions and update information to meet the demand of all classes in society. There are many website of adherents, religious organizations, groups, sects, parishes etc. ${ }^{31}$ Many websites have digitized religious works, translated works, books, newspapers, magazines, thesis, papers and conference booklets etc...to share with readers from all over the world. The information is rich in content and scientifically collected which enables the religious

30 Report released by Saigon Diocese in Dec 2011 and Report by Hoang Phap Board, Ho Chi Minh City Buddhist Association in November 2011.

31 Please visit popular website with the highest view rate : tgptphcm.net ; nguoiconggiao.com; cuuthe.com; vietcatholic.org củ a Công giáo và giacngo.vn; ban hoangphap.com.vn; thuvienhoasen.org; buddhismtoday.com; phatgiaonguyenthuy.com 
communities to update religious information anywhere with photos and video clips. Such information can not only create a worldwide effect but also a direct impact on beliefs and faith of the people. In addition, through internet, adherents can interact with the information sources and join online forum. The internet has become a basic need in the life of religious communities and facilitates the information dissemination of religious organizations.

\section{International relations and activities of religious organizations}

The clergy and adherents are sent to study overseas and attend conferences and seminars. They also involve in receiving foreign humanitarian aid, doing social charity, cooperating with other Vietnamese and overseas religious organizations, coordinating with NGO projects in Ho Chi Minh City. In recent years, the international relations of religious organizations, adherents and clergy in the city has developed especially those of Buddhism, Catholicism and Protestantism. These relations are not only broad and diverse but also tight and on a frequent basis. Vietnam Catholic Church is part of the World Catholic Church and under the Vatican Holy See. Therefore, Ho Chi Minh City Diocese has extensive relations with Catholic organizations and NGOs in many countries, mostly those in the United States of America, Germany, Australia, Italy, Canada, Japan and Korea or the Italy Bishops Council and Caritas Germany etc.Some bishops in Ho Chi Minh City are members of Asia Bishops Council. The bishops in Ho Chi Minh City together with those in other parts of the country visits Rome and other countries to attend religious activities of Vatican Holy See or of other religious organizations. ${ }^{32}$

Protestant branches and sects in Ho Chi Minh City originated from outside Vietnam and have close relations with other Protestant organizations in the world for a long time, especially with those in the United States of America, Korea, Singapore, Germany, North

32 http/ /: tgp-tphcm.net, dated 19/11/2012 
Europe etc....Those organizations receive significant financial aid from international organizations every year. ${ }^{33}$

Buddhist organizations in Ho Chi Minh City also have relations with those in the region and the world such as China, India, Cambodia, Laos, Thailand, Sri Lanka, Russia, Mongolia, France, the United States of America, Japan and join the World Buddhist organizations like Asia Buddhist Conference for Peace, World Buddhist Fellowship Union, and World Buddhist Summit Conference. Buddhism has around 350 million of adherents all over the world but mostly in Asia. Therefore, Buddhist organizations in Ho Chi Minh City have specifically paid attention to the international relations for training monks and building facilities. ${ }^{34}$

Islam in Ho Chi Minh City also has close relations with Islam in the South East Asia, one of the regions that has the largest number of adherents in the world. The relations with Islamic community in Malaysia are the best and most frequent due to historical reasons, family traditions, and language. According to a survey conducted on this topic in April 2009, there are 53 people out of total 125 adherents replied to have relatives or friends in Malaysia. Most of the Cham Islam students received scholarship to study at the International Islamic University, Malaysia.The Islamic organization received financial aid from Islamic Development Bank every year. In addition, Islam in Ho Chi Minh City also has close relations with Islamic organizations in Cambodia, Thailand, and Indonesia ${ }^{35 .}$

The international relations of religious organizations in Ho Chi Minh City reflects the rapid development of religions in the city. Though there are still some issues that need to be addressed, the international relations of religious organizations in Ho Chi Minh

33 The Government Committee of Religious Affairs, Report: project of investigation into the reality of Vietnam Evangelical Church: suggestions for policies, Hanoi, 2003, p 38-49.

34 Website: http//: www. Gdpt.vinhnghiem.com, dated 15/8/2011

${ }_{35}$ Nguyen Tan Dac and Ton Nu Quynh Tran, Islam community in Ho Chi Minh City and the relationship with Southeast Asia region,Ho Chi Minh City, 2000, p.158 
City on one hand helped them to have well trained clergy (dozens of clergy have $\mathrm{Ph} \mathrm{D}$ degree, Master of Theology, Master of Philosophy, and hundreds of clergy are studying overseas) and on the other hand has helped the world to know about the country, people and policy of freedom of religion in Vitenam.

\section{References}

Hue, Do Trinh. Culture, Religion and Beliefs in Vietnam through the Eyes of L.Cadiere. Hue: Thuan Hoa Publishing House, 2006.

Van Le, Ngo. Ethnic Groups and theirCcultures. Ho Chi Minh

City:Ho Chi Minh National University Publishing House, 2004.

----. Social Sciences and Cultures of Ethnic Groups. Ho Chi Minh City: Ho Chi Minh National University Publishing Hous, 2012.

----. (Ho Chi Minh City ) "Cham Culture from Religious Aspect", Conference on Cham Culture. Conducted byGeneral University, Ho Chi Minh City.

Phan Ngoc. Vietnam Culture and New Approach. Ha Noi: Information and Culture Publishing House, 1994

Phan Ngoc. Vietnam Cultural Identities. Ha Noi: Information and Culture Publishing House, 1998.

Phan, Xuan Bien. The South East: People and Culture. Ho Chi Minh: National University Publishing House, 2004.

----. (Ed.), The Cham Culture. Ha Noi: Social Sciences Publishing House, 1998.

Statistic of Ho Chi Minh City Religion Board, the Khmer people in Tan Binh District, Ho Chi Minh City, 1998.

Census Board of Ho Chi Minh City 1994 Census.

Nghi Doan . Revolutionary tradition of the Chinese in Ho Chi Minh City. Ho Chi Minh: Ho Chi Minh City Publishing, 1987.

Mac Duong. The Chinese society in Ho Chi Minh City after 1975: Potential and Development. Ho Chi Minh: Social Science and Humanities Publishing, 1994.

Thien Cam. "Is there a Catholic culture in Vietnam?". Hue Documents for internal use. 2000. 
Trinh Hoai Duc. Gia Đinh thanh thong chi/ Ha Noi: Education Publishing House. , Tran Van Giau (Ed.), (1987)

CulturalGeography of Ho Chi Minh City. Book 1. Ho Chi Minh: Ho Chi Minh City Publishing House, 1998.

Tran Hong Lien. Buddhism in Southern Vietnamese Community Ha Noi: Social sciences Publishing House, 1987.

Survey Data (2002) Statistics of Ho Chi Minh City Religion Board.

Ho Chi Minh City Religion Association Conference on 300 years of Buddhism in Gia Dinh - Sai Gon. Ho Chi Minh City: Ho Chi Minh City Publishing, 2001.

Cao Tu Thanh. Confucianism in the South. Ho Chi Minh: Ho Chi Minh City Publishing House, 1968).

Phan An. Chinese Temples: A Distinctive Feature of Ho Chi Minh City, Ho Chi Minh: Ho Chi Minh City Publishing, 1990.

----. The Southern Vietnamese. Ha Noi: Encyclopedia Publishing House, 2012.

----. The Chinese in the South, Ha Noi: Social Sciences Publishing House, 2005.

----. Khmer people in the South. Ha Noi: National Politic Publishing House, 2011.

Phan Thi Yen Tuyet. Housing, Dressing and Cuisine of People in Mekong Delta. Ha Noi: Social Science Publishing, 1993.

Kham Đinh Viet su thong giam cuong muc. Ha Noi: Education Publishing House. Le Qui Don, Phu Bien Tap Luc. Book I. Ha Noi: Social Sciences Publishing House, 2002.

Tran Xuan Hien "Results of religion work 2007". Religion Studies Journal, Vol.3. 2008.

Religion Council, Vietnam National Front. Report on Socialized Healthcare, Education and Charity Activities of Religions in Ho Chi Minh City, October, 2012.

Report released by Saigon Diocese in Dec 2011 and Report by Hoang Phap Board, Ho Chi Minh City Buddhist Association in November 2011. 
The Government Committee of Religious Affairs. (2003) Report:

Project of Investigation into the Reality of Vietnam Evangelical Church: Suggestions for Policies, Hanoi.

Vu Khieu. Vietnam Culture. Ha Noi: Social Sciences Publishing House, 1996.

----. Vietnam Confucius Family. Ha Noi: Social Sciences Publishing House, 1996.

Nguyen Tan Dac and Ton Nu Quynh Tran. Islam community in Ho Chi Minh City and the Relationship with Southeast Asia Region. Ho Chi Minh City. Social Sciences Publishing House, 2000 